\begin{tabular}{|c|c|c|c|c|c|c|c|c|c|c|c|}
\hline $\begin{array}{l}\text { 試 料 } \\
\text { 番 號 }\end{array}$ & $\begin{array}{c}\mathrm{S}_{2} \mathrm{Cl}_{2} \\
(\mathrm{cc})\end{array}$ & $\left(\begin{array}{c}\text { 㴓 } \\
\left({ }^{\circ} \mathrm{C}\right)\end{array}\right.$ & $\begin{array}{l}\text { 作用特間 } \\
\text { (分) }\end{array}$ & $\begin{array}{l}\text { 沃泰 覞 } \\
(\mathrm{A}-\mathrm{B})\end{array}$ & $\begin{array}{c}\text { 全 } \\
(\%)\end{array}$ & 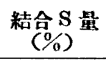 & $\begin{array}{c}\text { アセトシ抽出量 } \\
(\%)\end{array}$ & $\begin{array}{c}\text { 全祭春量 } \\
(\%)\end{array}$ & $\begin{array}{c}\text { 遊離 } \\
(\%)\end{array}$ & 備 & 考 \\
\hline 41 & 10 & 15 & 300 & & & & & & & 粘秱油 & 狀 \\
\hline 42 & 15 & " & 80 & 66.60 & 10.79 & 7.14 & 14.15 & 7.34 & 1.56 & 淡 黄 & 色 \\
\hline 43 & 20 & " & 50 & 51.68 & 13.52 & 9.56 & 4.57 & 7.72 & 2.01 & $" 1$ & \\
\hline 44 & 30 & " & 40 & 32.00 & 17.44 & 10.50 & 4.34 & 8.58 & 4.89 & 谨 & 色 \\
\hline 45 & 10 & 30 & 300 & & & & & & & 粘和油 & 狀 \\
\hline 46 & 15 & " & 60 & 70.93 & 10.69 & 8.10 & 10.82 & 8.53 & 1.69 & 谈 黃 & 色 \\
\hline 47 & 20 & " & 40 & 59.98 & 12.93 & 9.00 & 5.79 & 9.51 & 2.25 & " & \\
\hline 48 & 30 & " & 30 & 38.74 & 16.16 & 11.52 & 4.12 & 10.03 & 4.58 & 針 & 色 \\
\hline
\end{tabular}

を以て溶劑を多量に用ふる方が 結果良好なるもの今如し。 $\mathrm{Cl}$ 量 は作用溫度高き方大にして 量は之に反し小なり。 $\mathrm{S}: \mathrm{Cl}$ は $\mathrm{S}_{2} \mathrm{Cl}_{2}$ の添加量小にして作用温度高きとき小にして, $\mathrm{S}_{2} \mathrm{Cl}_{2}$ 添加量大な るとき叉作用溫度低きとさ大なり。此の傾向は觫油の場合に認め たると同樣なり。换言すれば $\mathrm{S}_{2} \mathrm{Cl}_{2}$ の添加量小なるとき又作用 溫度高きときは $\mathrm{Cl}$ の結合に比して S の結合は小なり。恐らく $\mathrm{S}_{2} \mathrm{Cl}_{2}$ の添加量少きときは定量的に $\mathrm{S}_{2} \mathrm{Cl}_{2}$ が附加せらる〉に反 乙, $\mathrm{S}_{2} \mathrm{Cl}_{2}$ 多きときは $\mathrm{Cl}$ の置換作用も可成り行はる〉もの〉如 し。又作用溫度高きときは $\mathrm{S}_{2} \mathrm{Cl}_{2}$ が能く結合するに反し，作用 溫度低きとさは附加せられたる $\mathrm{S}_{2} \mathrm{Cl}_{2}$ は $\mathrm{S}$ を與ふると同時 $\mathrm{Cl}$ は分解するに因るものならん。アセトン抽出量は $\mathrm{S}_{2} \mathrm{Cl}_{2}$ の添加 量少きもの大にして $\mathrm{S}_{2} \mathrm{Cl}_{2}$ 多量なるもの小なり。此の傾向は觫 油の場合と稍趣きを異にす。之は要するに前報の褐色フ っクチス に於て考察せると同じく $\mathrm{S}_{2} \mathrm{Cl}_{2}$ が飽和に達したるときアセトン 抽出量最小值を示し, $\mathrm{S}_{2} \mathrm{Cl}_{2}$ が過剩となるに及び却てアセトン抽 出量を增加するに因るものならんと考へらる。郎ち鰓油は鰊油に 比して不飽和度大にして $\mathrm{S}_{2} \mathrm{Cl}_{2}$ を多く吸收する結果にして, 触油 は此の程度の $\mathrm{S}_{2} \mathrm{Cl}_{2}$ の添加に於て既に過剩なるに反し鰮油は尚 飽和するに至らざるに因るものと考へらる。概して鰓油フ , クチ
スの品質優良にして容量にて $\mathrm{S}_{2} \mathrm{Cl}_{2}$ は油に對し $20 \%$ か適當する

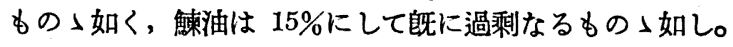

\section{總括}

鰊油及び鰮油につき溶劑として $\mathrm{CCl}_{4}$ を用ひ $\mathrm{S}_{2} \mathrm{Cl}_{2}$ による白 色フ、クチスの品質を吟味せり。何れも $\mathrm{S}_{2} \mathrm{Cl}_{2}$ を多量に用ふる ときは着色し質硬し。鰂油は鰊油よりも $\mathrm{S}_{2} \mathrm{Cl}_{2}$ を多く要し, 作 用は速かなり。ファクチス中の $\mathrm{S}: \mathrm{Cl}$ は何れも $\mathrm{S}_{2} \mathrm{Cl}_{2}$ の添加量 小なるとき又は作用溫度高きとき小にして, 之に反し $\mathrm{S}_{2} \mathrm{Cl}_{2}$ 量 大なるとき叉は作用溫度低きときは大なり。 $\mathrm{S}_{2} \mathrm{Cl}_{2}$ の添加量大な るときは附加作用以外に $\mathrm{Cl}$ の置換作用㙷著なり。アセトン抽出 量は褐色フっクチスに於けると同じく $\mathrm{S}_{2} \mathrm{Cl}_{2}$ 量が適當のとき最 小にして, 鯭油は $\mathrm{S}_{2} \mathrm{Cl}_{2}$ の添加量は油に對し約 $20 \%$ (容量)を適

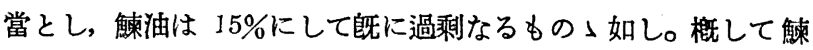
油に比して䲛油フっクチスは淡色柔軟にして良質なり。

第 1〜2 報に涉り實驗は木村萐信及び末廣三郎兩氏に負子處多 しっ兩氏の勞を謝す。又試料を提供せられたる神戶市瀧原化學工 場に謝意を表す。何想切なる御助言を賜りたる東北帝國大學西澤 教授に深謝す。

(燃料研究所石炭油化研究室)（昭和 14 年 2 月 23 日受理）

\title{
(119）低溫タールの高壓水素添加'第13 報)
}

モリブデン觸媒に於ける數種固形擔體の比較

\section{安東新午}

モリブデン化合物はタングステン化合物と共に殊に中油類の氣 相水素添加に於て解媒として缺くべからざるものなり。氣相水素 添加に際して使用すべき固形解媒としては，粉狀触媒を成型せし めたるもの又は固形の些體に觸媒物質を附着せしめたるもの等が 考虑せらる。本報に於ては後者の一例として最も一般的なる數種 の固形擔體並に夫等に加工を施したるものを使用し，之にモリブ デン化合物を附着せしめて得たる解媒を用ひて低溫タールピッチ 拔油の高壓水素添加を行ひ，各反碓生成物の收量及び生成油の性 質等を比較せり。

\section{試 料 及び觸 媒}

試料 次の如き低溫タールピ,チ拔パラフィン拢油を使用せり。 撫順炭を燃料研究所外熱式低溫乾溜盧にて乾溜して得たる低溫 タールを先づ容量 $3 \mathrm{k} l$ の蒸溜裝置にて殘洫がコークス狀となる 迄蒸溜し, 沸點 $200^{\circ} \mathrm{C}$ 以上の溜出油 $66 \mathrm{vol} \%$ を得たり。次で $-12^{\circ} \mathrm{C}$ に泠却し砝濾器を使用してパラフィンを分離し, 斯くして 得たるピ。チ拢パラフィン拔油を 11 .のフラスコにて蒸溜し, 沸點 $200^{\circ} \mathrm{C}$ 以下の溜分を除去して試料とせり。比重 $\left(d_{2}^{4} 0\right) 09650$ にし て, $34.3 \mathrm{wt} \%$ の酸性油を含有し, 蒸溜結果は次の如し (wt \%を 示す)。

$\begin{array}{ccc}250^{\circ} \mathrm{C} \text {. 以 } & 250 \sim 3 \mathrm{ro}^{\circ} \mathrm{C} & 300^{\circ} \mathrm{C} \text { 以上 } \\ 24.1 & 37.8 & 33.1\end{array}$

元素分析結果は次の如し。

$\begin{array}{ccccc}\text { 炭 素 } & \text { 水 素 } & \text { 酸素(羑) } & \text { 室 素 } & \text { 硫 黄 } \\ 84.26 & 9.56 & 5.31 & 0.38 & 0.49\end{array}$

触媒 各觸媒には常に $6.0 \mathrm{~g}$ の化學用硫黄華を加へて使用せり。 賽驗番號 1 に於ては市販の分析用モリブデン酸アンモニウム (結晶) を粉碎して得たるすの $30 \mathrm{~g}$ を其の儘使用せり。 實驗番號 2 - 12 に於ける觸媒は，何れも次記の如き芜體に $30 \mathrm{~g}$ 
のモリブデン酸アンモニウムを其の 水溶液より均一に附着せし め, 湯浴にて乾燥せる後電氣爐內にて約 $500^{\circ} \mathrm{C} に$ 於て 3 時間燒成 して得たるものなり。何れる生成せる觸媒の全量（第 1 表に示せ る量)を使用せり。

アルミナゲル（a）(賽驗番號 2) 小島製鹿印粒狀アルミナゲル を $100^{\circ} \mathrm{C}$ に於て 1 書夜乾燥せるもの $90 \mathrm{~g}$ を使用せり。粒の大き さは凡そ米粒大乃至小豆大なり。

アルミナゲル (b) (實驗番號 3) 加藤製香闌印粒狀アルミナゲ ルを約 $600^{\circ} \mathrm{C} に て 1$ 時間燒成して得たるもの $90 \mathrm{~g}$ を使用せり。 粒の大きさは凡そ小豆大なり。

活性白土(實驗番號4) 武田白土工業株式會社水澤工場製の粒 狀活性白土を $100^{\circ} \mathrm{C}$ に於て乾燥せるもの $90 \mathrm{~g}$ を使用せり。粒の 大きさは凡そ米粒大なり。

石綿（實驗番號 5) 市販の上質長繊維不綿を $100^{\circ} \mathrm{C} に$ 於て乾燥 せるもの $15 \mathrm{~g}$ を使用せり。

輕石（實驗番號 6) 市販の精製粒狀輕石を $100^{\circ} \mathrm{C}$ に於て乾燥せ るもの $50 \mathrm{~g}$ を使用せり。粒の大きさは凡そ大豆大なり。

不綿・アルミナゲル（鿒驗番號 7） 前記加藤製アルミナゲルを $100 \mathrm{C}$ に於て乾燥せる後乳鉢にて粉碎せるもの $30 \mathrm{~g}$ を, $15 \mathrm{~g}$ の 石綿纎維上に附着せしめて得たるものを使用せり。

石綿・水酸化アルミニウム（賽驗番號 8）小西製犬印硝酸アル ミニゥム $147.2 \mathrm{~g}\left(\mathrm{Al}_{2} \mathrm{O}_{3}\right.$ として $20 \mathrm{~g}$ に相當す）の水溶液にアン モ二ア水を加へて生成せる水酸化アルミニウムの沈澱を, $15 \mathrm{~g}$ の 石綿繊維上に附着せしめたるものを使用せり。

石綿・活性白土（實驗番號 9) 前記水澤工場製の粉末狀活性白 土を $100^{\circ} \mathrm{C}$ に於て乾燥せるもの $30 \mathrm{~g}$ を, $15 \mathrm{~g}$ の石綿瀻維上に附 着せしめて得たるものを使用せり。

不綿・迋藻土（實驗番號 10）加藤製ヨ,ト印粉末狀珪藻土を $100{ }^{\circ} \mathrm{C}$ に於て乾燥せるもの $30 \mathrm{~g}$ を, $15 \mathrm{~g}$ の不綿繊維上に附着せ しめて得たるものを使用せり。

石綿・酸化ニッケル（實驗番號 11）加藤製香蘭印碓酸ニッケル $77 \mathrm{~g}$ (NiO として $20 \mathrm{~g}$ )を其の水溶液より $15 \mathrm{~g}$ の不綿纎維上に 附着せしめたるものを, 約 $560^{\circ} \mathrm{C}$ に燒きて酸化ニッケルを生成 せしめたる後に使用せり。

輕不・アルミナゲル（實驗番號 12） 前記加藤製アルミナゲル を $100 \mathrm{C}$ に於て乾燥せる後乳鉢にて粉碎せるもの $30 \mathrm{~g}$ を, $50 \mathrm{~g}$ の 輕不前記と同一のもの)に附着せしめて得たるものを使用せり。

何れの觸媒も見掛けの容積は略同樣にして, 凡そ $203 \mathrm{cc}$ 內外な b。

\section{䔈驗方法及び結果}

反硫峈件 各實驗に於て第 $8,9,10,11$ 及び 12 報（本誌, 昭 和 $13,41,632,817,854$; 昭和 14, 42,42, 256) に於けると同一 の包轉式オートクレーヴを使用せり。內谷積 $4,930 \mathrm{cc}$ を有す。

試料は常に $300 \mathrm{~g}$ を用ひ, 第 1 表に示せる量の觸媒の他に常に $6 \mathrm{~g}$ の硫黄を加へたり。初熨は總て $100 \mathrm{~atm}\left(0^{\circ} \mathrm{C}\right)$ とし, 約 $440^{\circ} \mathrm{C}$ に於て エ時間の反應を行ひたる後放冷せり。反應區として左に記 せる值は反應溫度に達したる時の枤力を示し, 何れも實驗中の最 高厭に一致せり。右に記せるは反應溫度に於て 1 時間經過せる際 の㸡力を示す。終医は室温 $\left(11-24^{\circ} \mathrm{C}\right)$ に於ける值を記錄せり。 少壓大水素量は $431 l$ (標準狀態の純水素として)にして, 試料の 12.93 wt \% に相當せり。
各實驗に於ける反應條件は第 1 表に示すが如し。但し溫度を反 應溫度迄上昇せしむるに一般に 2 時間內外を要せり。

\begin{tabular}{|c|c|c|c|c|c|c|c|c|}
\hline $\begin{array}{l}\text { 蜜驗 } \\
\text { 番號 }\end{array}$ & $\begin{array}{c}\text { 試料 } \\
\mathrm{g}\end{array}$ & $\overbrace{\text { 擔體種類 }}^{\begin{array}{c}\text { 第 } 1 \text { 表 } \\
\text { 媒 }\end{array}}$ & $\mathrm{g}$ & $\begin{array}{l}\text { 應 住 } \\
\text { 初䐎 } \\
\left(0^{\circ} \mathrm{C}\right) \\
\text { atm }\end{array}$ & 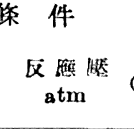 & $\begin{array}{c}\text { 終擝 } \\
\text { (室温) } \\
\text { atm }\end{array}$ & 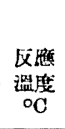 & $\begin{array}{l}\text { 反礁 } \\
\text { 時圽 } \\
\text { (時) }\end{array}$ \\
\hline 1 & 300 & 使 用 せず & 30 & $1 C 0$ & $243 \sim 230$ & 74 & 400 & 1 \\
\hline 2 & $"$ & 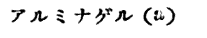 & 78 & " & $234 \sim 219$ & 67 & 441 & "I \\
\hline 3 & " & アルミナゲル（b) & 114 & " & $235 \sim 217$ & 64 & " & " \\
\hline 4 & " & 活 性 白土 & 109 & " & $240 \sim 225$ & 72 & 440 & "I \\
\hline 5 & " & 石 & 38 & " & $257 \sim 241$ & 82 & $"$ & " \\
\hline 6 & " & 相 & 72 & " & $250 \sim 233$ & 75 & 441 & " \\
\hline 7 & " & 石綿・アルミナゲル & 59 & $"$ & $248 \sim 228$ & 74 & " & " \\
\hline 8 & " & $\begin{array}{c}\text { 石絈・水酸化アルミ } \\
=\text { }\end{array}$ & 58 & " & $243 \sim 225$ & 73 & 440 & " \\
\hline 9 & " & 石䄸・活性白土 & 67 & " & $247 \sim 228$ & 73 & 442 & " \\
\hline 10 & $"$ & 石綿・珪 澡 土 & 68 & " & $249 \sim 230$ & 74 & 440 & " \\
\hline 11 & " & 石線・酸化=ッケル & 58 & $"$ & $249 \sim 232$ & 74 & " & " \\
\hline 12 & " & 瑟石・アルミナゲル & 94 & ' & $235 \sim 221$ & 67 & "I & " \\
\hline
\end{tabular}

反憵生成物 各賽驗に於ける反應生成物の收量並に水素消費量 等は第 2 表の如し。ガス狀生成物中より活性炭に依りて吸着せら れたる物質を活性炭吸着物とし, 吸着せられざりし炭化水素は總 てメタン $(0.8 \mathrm{~g} / \mathrm{l})$ より成るものと假定して其の收量を求めたり。 尚ガス狀生成物中より活性炭の前にて苛性カリ溶液, 毁化カルシ ウム及びッーダ不灰に依りて吸收せられたる物質の量の合計は總 ての實驗に於て試料の $0.2 \sim 0.4$ w $\%$ を示せり。生成ガスは炭酸 ガスを含有せず，一酸化炭素の含有量は何れも $0.2 \mathrm{vol} \%$ 以下を 示せり。

第 2 表 反隹生成物（試料に對する wt \%を示す）

\begin{tabular}{|c|c|c|c|c|c|c|c|c|}
\hline \multirow{2}{*}{ 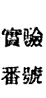 } & \multicolumn{2}{|c|}{ 生成油 } & \multirow{2}{*}{$\begin{array}{c}\text { 生减水 } \\
\%\end{array}$} & \multirow{2}{*}{$\begin{array}{c}\text { 活性炭 } \\
\text { 吸者物 } \\
\% \\
\%\end{array}$} & \multicolumn{2}{|c|}{ 生成ガ } & \multirow{2}{*}{$\begin{array}{c}\text { 水䇣 } \\
\text { 消刑 } \\
\% \\
\%\end{array}$} & \multirow{2}{*}{$\begin{array}{c}\text { 損 } \% \\
\%\end{array}$} \\
\hline & $\%$ & $d_{20}^{20}$ & & & X8 & 水絜 & & \\
\hline 1 & 76.3 & 0.8106 & 6.7 & 14.8 & 4.0 & 8.07 & 4.86 & 2.4 \\
\hline 2 & 77.0 & 0.8021 & 5.1 & 15.0 & 5.6 & 7.19 & 5.74 & 2.7 \\
\hline 3 & 77.5 & 0.8179 & 5.2 & 15.5 & 4.2 & 6.96 & 5.97 & 3.3 \\
\hline 4 & 77.6 & 0.8143 & 5.2 & 14.5 & 4.6 & 7.91 & 5.02 & 2.9 \\
\hline 5 & 74.1 & 0.8606 & 4.9 & 14.3 & 8.4 & 8.41 & 4.52 & 2.4 \\
\hline 6 & 77.6 & 0.8329 & 5.0 & 14.2 & 5.7 & 8.32 & 4.61 & 1.9 \\
\hline 7 & 78.5 & 0.8329 & 4.9 & 14.2 & 3.9 & 8.01 & 4.92 & 3.0 \\
\hline 8 & 77.3 & 0.8289 & 5.1 & 15.9 & 3.9 & 7.89 & 5.04 & 2.6 \\
\hline 9 & 76.2 & 0.8270 & 5.9 & 14.6 & 4.7 & 8.13 & 4.80 & 3.2 \\
\hline 10 & 77.3 & 0.8257 & 51 & 14.7 & 4.8 & 8.24 & 4.69 & 2.4 \\
\hline 11 & 74.8 & 0.8351 & 5.8 & 15.6 & 6.4 & 7.91 & 5.02 & 2.2 \\
\hline 12 & 78.9 & 0.8060 & 50 & 13.4 & 5.2 & 7.64 & 5.29 & 2.5 \\
\hline
\end{tabular}

第 3 表 生成油の藻溜結果 (wt\%を示す)

\begin{tabular}{|c|c|c|c|c|c|c|c|c|c|}
\hline & $\begin{array}{c}\text { 初溜㩆 } \\
{ }^{\circ} \mathrm{C}\end{array}$ & $\begin{array}{c}100^{\circ} \mathrm{C} \\
\text { 以下 } \\
\%\end{array}$ & $\begin{array}{c}100 \sim \\
150 \\
\%\end{array}$ & $\begin{array}{c}200 \\
\%\end{array}$ & $\begin{array}{c}\text { 以下 } \\
\text { 合計 } \\
\%\end{array}$ & $\begin{array}{c}2 \mathrm{CO} \sim \\
250 \\
\%\end{array}$ & $\begin{array}{c}250 \sim \\
300 \\
\%\end{array}$ & $\begin{array}{l}\text { 乾點 } \\
{ }^{\circ} \mathrm{C}\end{array}$ & $\begin{array}{c}\text { 殘渣 } \\
\%\end{array}$ \\
\hline 1 & 47 & 11.7 & 33 & 27.5 & 72.2 & 21.3 & 5 & 28 & 1.3 \\
\hline 2 & 41 & 3.9 & & .8 & 75.5 & 18.7 & & 28 & 10 \\
\hline 3 & 49 & 11.2 & $3 i$ & 240 & 69.0 & 25. & & $2 \varepsilon$ & 1.2 \\
\hline 4 & 40 & 120 & & 4.5 & 71.9 & 21. & & 298 & 1.2 \\
\hline 5 & 49 & 7.8 & 19. & .0 & 52.9 & 28.6 & 13 & - & 5.0 \\
\hline 6 & 41 & 10.0 & 25 & 25.7 & 60.8 & 25 & & - & 3.5 \\
\hline 7 & 47 & 10.0 & 27 & 27.7 & 65.2 & 25. & & 297 & 1.4 \\
\hline 8 & 45 & 10.4 & 31 & & 65.5 & 25 & & 234 & 1.6 \\
\hline 9 & 37 & 10.0 & 26 & & 63.8 & 23 & & - & 2.5 \\
\hline- & 39 & 10.8 & 27 & 25.9 & 63.9 & 24. & & - & 2.5 \\
\hline 11 & 51 & 5.4 & 32.5 & 22.7 & 60.6 & 26.5 & 10.9 & $\ldots$ & 2.0 \\
\hline 12 & 41 & 13.4 & 28.7 & 29.4 & 71.5 & 21.7 & 5.7 & 298 & 1.1 \\
\hline
\end{tabular}


生成油は無色乃至淡黄色にして, 何れも酸性油を全く含有せず。

各實驗に於て生成油を枝附フラスコに探りて蒸溜せるに第 3 表 の如き結果を得たり。

生成油各溜分の比重は第 4 表の如し。

第 4 表生成油各溜分门比重

\begin{tabular}{|c|c|c|c|c|c|}
\hline 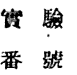 & $\begin{array}{c}103^{\circ} \mathrm{C} \text { 以下 } \\
d_{20}^{20}\end{array}$ & $\frac{100 \sim 150}{d_{20}^{20}}$ & $\begin{array}{c}150 \sim 200 \\
d_{20}^{20}\end{array}$ & $\begin{array}{c}200 \sim 250 \\
d_{2 j}^{20}\end{array}$ & $\begin{array}{c}250 \sim 300^{\circ} \mathrm{C} \\
d_{20}^{20}\end{array}$ \\
\hline 1 & 0.6967 & 0.7876 & (1.8411 & 0.8762 & 0.8847 \\
\hline 2 & 0.7017 & 0.7837 & 0.8420 & 0.8824 & 0.8975 \\
\hline 3 & 0.6993 & 0.7823 & 0.8439 & 0.8869 & 0.9123 \\
\hline 4 & 0.6962 & 0.7856 & 0.8492 & 0.8940 & 0.9227 \\
\hline 5 & 0.7018 & 0.7824 & 0.8573 & 0.9172 & 0.9515 \\
\hline 6 & 0.6864 & 0.7881 & 0.8508 & 09044 & 0.9380 \\
\hline 7 & 0.6968 & 0.7866 & 0.8529 & 0.9001 & 0.9276 \\
\hline 8 & 0.6989 & 0.7850 & 0.8440 & 0.8915 & 0.9134 \\
\hline 9 & 0.6876 & 0.7841 & 0.8492 & 0.9013 & 0.9311 \\
\hline 10 & 0.6860 & 0.7925 & 0.8515 & 0.9058 & 0.9356 \\
\hline 11 & 0.7033 & 0.7844 & 0.8458 & 0.8937 & 0.9218 \\
\hline 12 & 0.6936 & 0.7827 & 0.8372 & 0.8855 & 0.9057 \\
\hline
\end{tabular}

輕㠫油分の分析 數個の實驗に於て, ‘夫沸點 $200^{\circ} \mathrm{C}$ 以下の全 輕質油溜分を集めて混合し，第 8 報（前記參照）に於けると同樣 の方法に從ひて分析を行へり。

第 5 表は不飽和炭化水素を除去せる輕質油分を, 小型精溜管を 附したるフラスコにて分溜せる際の結果を示す。

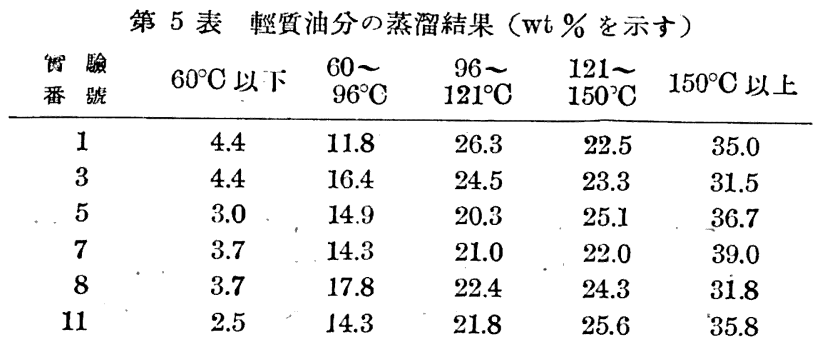

第 6 裴 慗質油各溜分の分析結果 (1)（wt\%を示す)

\begin{tabular}{|c|c|c|c|c|c|c|c|c|c|}
\hline \multirow{2}{*}{$\begin{array}{l}\text { 谄驗 } \\
\text { 番號 }\end{array}$} & \multicolumn{3}{|c|}{$60 \sim 96^{\circ} \mathrm{C}$} & \multicolumn{3}{|c|}{$96 \sim 121^{\circ} \mathrm{C}$} & \multicolumn{3}{|c|}{$121 \sim 150^{\circ} \mathrm{C}$} \\
\hline & 芳香族 & +⿱丶万仒 & $\begin{array}{l}\overbrace{1} \\
>_{1}\end{array}$ & 芳香族 & $\begin{array}{l}+7 \\
\overline{7}\end{array}$ & $\begin{array}{l}{ }^{\circ} \\
>_{1}\end{array}$ & 芳香族 & $\begin{array}{l}+7 \\
72\end{array}$ & $\begin{array}{l}\text { パン } \\
>_{1}\end{array}$ \\
\hline 1 & 19 & 42 & 39 & 35 & 47 & 18 & 54 & 33 & 13 \\
\hline 3 & 16 & 48 & 36 & 31 & 52 & 17 & 48 & 40 & 12 \\
\hline 5 & $2 J$ & 43 & 37 & 36 & 47 & 17 & 62 & 27 & 11 \\
\hline 7 & 19 & 45 & 36 & 36 & 47 & 17 & 56 & 32 & 12 \\
\hline 8 & 20 & 49 & 31 & 37 & 47 & 16 & 57 & 31 & 12 \\
\hline 11 & 19 & 47 & 34 & 34 & 50 & 16 & 54 & 35 & \\
\hline
\end{tabular}

〔備考〕不能和炭化水素を除外せる結果を示す。

第 7 表 軖質油各溜分の分析結果（2）（wt\%を示す）

\begin{tabular}{|c|c|c|c|c|c|c|c|}
\hline \multirow{2}{*}{ 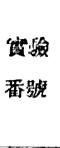 } & \multirow{2}{*}{$\begin{array}{c}200^{\circ} \mathrm{C} \\
\text { 以 F } \\
\text { 不能利 } \\
\%\end{array}$} & \multicolumn{3}{|c|}{$60-150^{\circ} \mathrm{C}^{*}$} & \multicolumn{3}{|c|}{$150^{\circ} \mathrm{C}$ 以上 } \\
\hline & & $\begin{array}{c}\text { 芳香族 } \\
\% \\
\end{array}$ & $\begin{array}{l}\text { ナフ } \\
\text { テン } \\
\%\end{array}$ & $\begin{array}{c}\text { パラ } \\
\text { フィン } \\
\%\end{array}$ & $\begin{array}{c}\text { 芳香族 } \\
\% \\
\end{array}$ & $\frac{\text { 饱 }}{\%}$ & 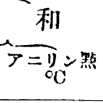 \\
\hline 1 & 0.7 & 39.0 & 40.8 & 20.2 & 57.2 & 428 & 60.0 \\
\hline 3 & 0.4 & 33.3 & 46.6 & 20.1 & 57.2 & 42.8 & 58.2 \\
\hline 5 & 0.9 & 42.9 & 37.8 & 19.3 & 77.0 & 23.0 & 61.9 \\
\hline 7 & 0.7 & 39.4 & 40.7 & 19.9 & 68.1 & 31.9 & 59.6 \\
\hline 8 & 0.6 & 39.8 & 41.5 & 18.7 & 62.5 & 37.5 & 58.6 \\
\hline 11 & 0.7 & 38.7 & 43.1 & 18.2 & 63.3 & 36.7 & 58.2 \\
\hline
\end{tabular}

[借考] *不佗和炭化水素を除外せる結果走示す。
不䳌和炭化水素を除去せる $60 \sim 96^{\circ} \mathrm{C}, 96 \sim 121^{\circ} \mathrm{C}$ 並に 121 $150^{\circ} \mathrm{C}$ 各溜分中の芳香族, ナフテン及びパラフィン炭化水素含有 量は第 6 表に示すが如し。

輕質油分の不飽和炭化水素含有量，第 5 表及び第 6 表の結果よ り算出せる $60 \sim 150^{\circ} \mathrm{C}$ 溜分の組成並に $150^{\circ} \mathrm{C}$ 以上溜分の分析絬 果は第 7 表に示すが如し。

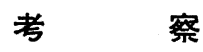

本報の實驗は低溫タールピッチ拔油に高塺水素添加を行ひて輕 質油化せしむるに當り，モリブデン化合物を數種の固形擔體に附 着せしめ更に硫黄を加へたる觸媒に於て，层體の種類が各反應生 成物の收量及び生成油の性質に對し凡そ如何なる影響を及注すや を求めたる娥㣁實驗なり。固形觸媒を製造するには粉末狀觸媒を 適當に成型せしもる方法及び觸媒物質を適當なる固形の擔體に附 着せしむる方法等が考慮せられ，何れが優れたる方法なりやに關 しては未だ決定的の報告を認めず。本報に於ては後者の一例とし て, 先づアルミナゲル (2 種), 活性白土, 石綿及び輕石を固形售 體として使用し比較を行へり。次に夫等の中不綿は效力最も劣れ るも耐破碎性に富む特徵を有するを以て, 其の瀻維上にアルミナ ゲル, 水酸化アルミニゥム, 活性白土, 珪藻土又は酸化二ッヶル の粉末を附着せしめたるものを擔體として使用し活性度の上昇を 計れり。佾輕石に就ても同樣の目的を以てアルミナゲルの粉末を 附着せしめたるものを擔體として試驗を行へり。

固形觸媒は工業的には反應空內に充して長時間に互り，主とし て中油類の氣相水素添加に使用すべきものなり。從て活性度の大 なると同時に耐久力の大なる事を必要とす。然れども本實驗の方 法に於ては各觸媒に就て1包宛の水素涯加を行ひたるのみなるを 以て, 初期の活性度を比較し得たるに止るなり。份試料ピッチ拔 油は, 工業的に氣相水素添加に使用する中油 (一般に沸點 $325^{\circ} \mathrm{C}$ 以下）に比し稍沸點の高き溜分を含有せり。

本報の各實驗に於て次の如き事實を認め得へし。

(1) アルミナゲルは英國燃料研究所 (Technical Paper No. 41 of Fuel Research, 1935) の試驗に依りて優れたる效果を有する を認められたるものなり。本報に於て使用せる2 種のアルミナゲ ルも亦顯著なる效果を示し, 多量の輕質油を生成せり。(實驗番 號 2 及び 3) 佮兩者の實驗結果は概して良く一致せり。

（2）活性白土を水素添加用解媒の擔體として使用する事に關し ては未だ研究發表を見ず。本報に於て使用せる活性白土（實驗番 號 4) はアルミミナ゙ルルに㖓匹敵する效果を示し, 兩者の實驗結果 は類似せる值を示せり。

（3）擔體を使用せずして粉末狀のモリブデン酸アンモニウム （嘪驗番號 1）を用ひたる場合に, 實驗結果はアルミナゲル又は活 性白土を擔體とせる實驗番號 2 4 と略類似し, 生成油の輕質油 含有量に大差を認めず。

（4）不綿は從來一般觸媒の擔體として最も廣く使用せられたる 物の一つにして，柔㳄性を有し耐破碎性に富み且つ見掛上の表面 積大なる特徽を有す。然れども本報の實驗に於て石綿を擔體とせ る觸媒（實驗番號 5) はアルミナゲル及び活性白土の場合に比し 著しく劣れる效果を示し, 多量のメタンを生成せるにも拘らず生 成油の輕質油分含有量甚だしく小なり。

（5）輕石も極めて一般的なる擔體にして安價なる利點を有す。 本報の賽驗に於て輕不を据體とせる觸媒（賽驗番號 6) は，不綿 
よりは優れたるも活性白土又はアルミナゲルよりは少れる效果を 示し, 生成油の輕質油分含有量は兩者の略中間に在り。

（6）不綿緎維上に有效なる擔體の粉末を附着せしめて得たる物 を捻體として使用せば，不綿の特徵を失ふ事無く而も活性度の大 なる觸媒を製出し得るものと预想せらる。本報に於ては粉末据體 としてアルミナゲル (實驗番號 7), 水酸化アルミニウム（實驗番 號 8), 活性白土 (實驗番號 9) 並に珪藻土（實驗番號 10）を選 び, 夫々一定量の石綿に附着せしめたる物を擔體として試驗せる に何れも殆ど匹敵せる結果を示せり。而して何れも粒狀のアルミ ナゲル又は活性白土の場合よりは輕質油の生成量秒小なるも, 不 綿を單獨に使用せる場合よりは著しく好結果を得たり。

份同樣の目的を以て石綿に酸化ニッヶルを附着せしめたる擔體 （實驗番號 11）を使用せるに，活性度の上昇を認め得たるも輕質 油の生成量は前記 4 者の場合に比して稍少し。

（7）輕石にアルミナゲルの粉末を附着せしめて得たる擔體（惯
驗番號 12) を使用せる觸媒は粒狀アルミナゲルを用ひたるものと 略同樣なる活性度を示し，輕質油の生成量互に匹敵せり。

（8）各触媒を通じて生成油, 活性炭吸着物及びメタンの收量は 概して县著なる相違を認めず。

（9）生成油各溜分の比重は何れの觸媒の場合にも殆ど匹敵せる 値を示せり。

（10）生成輕質油各溜分の分析を行ひたる實驗に於て, 炭化水素 組成は何れも略類似せる結果を示せり。但し粒狀アルミナゲルを 擔體とせる實驗番號 3 に於ては, 比較的多量のナフテン炭化水素 を生成するを認めたり。

(11) 生成輕質油各溜分の分析結果に於て, 蒸浽範凰の上昇する に從ひて芳香族炭化水素含有量を篁しパラフィン炭化水素の含有 量を減少せり。

本研究に當りては所員牛場紀典氏心熱心なる協力を得たり。

(早秠田大學理工學部應用化學科)（昭利 14 年 3 月 9 日受理）

\section{(120) 油類媒質內還 元觸媒 9 研究 (第 2 報) 﨡酸ニッケルに對するニ,三物質添加の影響}

$$
\text { 山口 榮一 ·山田元四郎 · 中山總一郎 }
$$

前報（本誌 40,801）に於て炭酸ニッケルと炭酸銅の混合物に

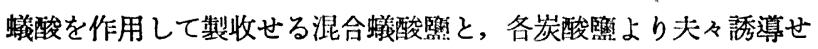
る蟻酸盒の機械的混合物を比較し前者の大豆油中に於る分解溫度 が後者より低き事を述べたり。之は水素を吹込みつ〉分解せる場 合なるが，分解と同時に大豆油の水素添加も並行して進行せり。

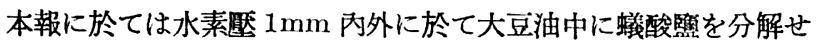
る場合に就て述へんとす。占銅以外に二, 三の物質添加の影響を 記せり。

所謂振盪法によりて常熨に於ける油脂水素添加觸媒の活力を比 較するに當り, 大氣慰及び氣溫の變化に伴ふ吸收水素容積の照減 に對する補正を省く目的を以て著者等は反應荟と水の電解器。を 結合し, 電解に要せる電氣量より吸收水素量を求むる方法を用ひ たり。

\section{寞 驗 裝 置}

1. 反礁埋 テレックス丸底圓筒 $(4.5 \times 15 \mathrm{~cm})$ の上端に同質の

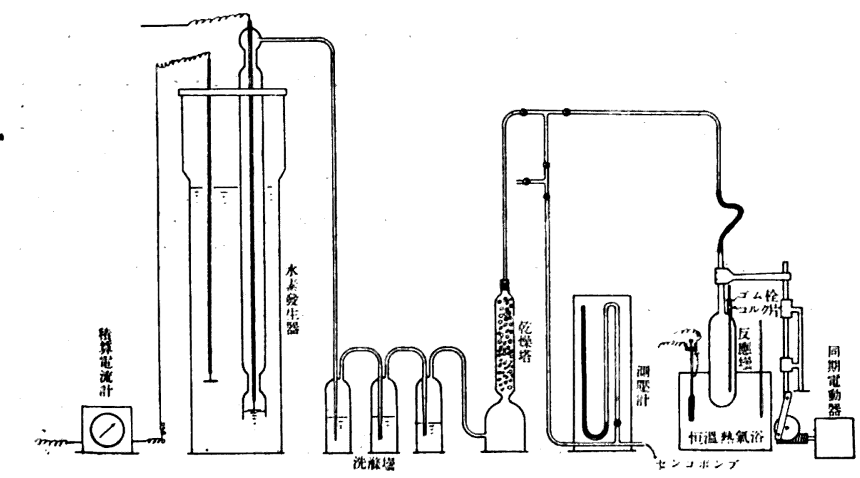

管 $(0.7 \times 15 \mathrm{~cm})$ を熔封せるものにして肉厚ゴム管及びT字管を經 て水素供給管或ひは排氣ポンプに接續す。圓筒部の肩には溫度計 插入口あり，木烃薄板にて下面を被覆せるゴム栓を附したる溫度 計にて之を密閉す。

2. 振浻機 同期電動機,ウォームギアの組合せにより反應濹索 持クランプを上下に運動せしむ。每分振溋數 360 包, 振幅 $2.5 \mathrm{~cm}$ 。

3. 熱莱浴 溫度調篩器を附せる電熱空氣浴にして反應坛內の 油溫を所定溫度 $\pm 2^{\circ}$ に保ち得るものなり。

4. 水素弡生器 稀硫酸丽解器なり。陰極は高さ $60 \mathrm{~cm}$, 徑 5 $\mathrm{cm}$ のガラス鐘內のガラス管に熔封せる白金圓板にして, ガラス 鐘を滿せる水素力゙減じ始もる時は稀硫酸の液面は陰極に接觸し電 解が始まり直ちに自動的に水素を補給す。ガラス鐘の上端は水素 洗滌歠乾燥荅等を經て, 反應堔に連なる故, 後者に於て反應せる量 と等しき量の水素を發生す。されば反應丵に於る刻々の水素反應 量は電解に要せる電氣量より知るを得たり。電流效䒺の變動, 陰

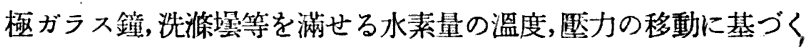
變化等により誤差入り來る虞ありし䉆電氣量より求めたる水素吸 收量と生成硬化油の最終沃素價とを比較せり。兩者の差は沃素價 2 單位以下にして本實驗の目的に對しては支障なき事を知れり。

5. クーロメーター 主として銅クーロメーターを用ひたり。 一部は橫河製積算電流計を用ひて行ひたり。後者は使用簡便なる も確度の點に於て些か少れるを認めたり。

\section{操作}

1. 空試驗 次項水素添加試驗に於る說明の如く水素供給前に 於る反應堛の内部は $1 \mathrm{~mm}$ 以下に排氣しある故, 前節 1 項に記せ るT字管の兩活栓より反應浑队部に至る部分を寒驗溫度に於て充 涔すへきき水素量を求り, 之を水素總量より控除し反應水素量とせ 